\title{
Socio-Economic and Communication Profile for using Cashless System by Respondents
}

\author{
Manisha Ohlan ${ }^{1}$, Ella Rani $^{1}$ and C.D. Autade ${ }^{2}$ \\ ${ }^{1}$ Department of Extension Education and Communication Management, \\ I. C College of Home Sciences and College of Agriculture, CCS Haryana Agricultural \\ University, Hisar, Haryana, India \\ ${ }^{2}$ Mahatma Phule Krishi Vidyapeeth, Rahuri, Maharashtra, India
}

*Corresponding author

Keywords

Cashless economy, Utilization, Credit card, Independent profession

Article Info

Accepted:

07 October 2019

Available Online:

10 November 2019

\section{A B S T R A C T}

Cashless economy is an economy where transactions can be done without necessarily carrying physical cash as a means of exchange of transaction but, rather with the use of credit or debit card payment for goods and services (Ejiro, 2012). The present study was conducted in Hisar district of Haryana state covering 200 respondents from two localities viz., rural and urban. Results shows that majority of respondents from below 35 years of age group were graduated and unmarried, who had nuclear type of family having upto 5 members in a family and belonged to general caste and had no membership. The respondents had their own independent profession with the monthly income above Rs.10, 000, who had pucca house and were landless. majority of respondents had possession of Cable TV, followed by television and newspaper and had high mass media exposure. Most of the respondents had high utilization of localite sources and low utilization of cosmopolite sources and exposure of PayTm for using cashless system, followed by credit card and internet banking.

\section{Introduction}

The government has implemented a major change in economic environment by demonetizing the high value currency notes of - Rs. 500 and Rs. 1000 from $8^{\text {th }}$ November 2016 and push India towards cashless future
(Shopard, 2016). The government is working at various levels to reduce the dependence on cash. Lucky GrahakYojna, Digi DhanVyapaarYojna are the two schemes for customers and traders to promote mobile banking and e-payments. To encourage and strengthen cashless economy it is important to 
inculcate the habit of making e-payments like mobile banking, Ru-pay cards, UPI, USSD these are means and methods of digital payments (Garg and Panchal, 2017).

Less cash economy is in the interest of everyone and it will help in creating a clearer economy in future. Government have also introduced Aadhar based payment system, this is for those people who do not have cards or mobile phones. Reducing Indian economy's dependence on cash is desirable for a variety of reasons (Swetha and Venkatesh, 2019). To control counterfeit notes that could be contributing to terrorism it also affect the monetary policy of our country and to eliminate the -black money, curbs illegal activities altogether. The latest World Bank report has mentioned that the demonetisation will not have any long-term adverse effect on the health of Indian Economy. Rather it will prove beneficial with growth of the Indian economy rising to 7.6 per cent in fiscal year 2018. Liquidity expansion in the banking system post-demonetisation has helped the banks to lower lending rates, which in turn is bound to lift economic activity. Present study was planned to explore awareness and opinion, assess utilization of cashless payment methods and identify constraints in utilization of cashless system.

\section{Materials and Methods}

The study was conducted in Hisar district of Haryana state selected purposively in both rural and urban areas. For rural respondents, from Hisar district two villages; Ludas and Shahpur were selected randomly. For urban respondents, two localities; Sector-14 and Sector-15 from Hisar city were selected randomly to assess awareness and opinion about cash less system of the respondents. A total of 200 respondents which comprised of 100 rural respondents (25 females, 25 males) from each village and 100 urban respondents
(25 females, 25 males) from each locality having at least higher secondary education were selected purposively. viz.,. A well structured interview schedule was used for awareness and opinion selected about demonetization and cashless system as a tool for data collection. Data were collected personally by the researcher. Statistical tools applied for data analysis such as frequency, percentages, weighted mean score and rank.

\section{Results and Discussion}

This section includes the socio-economic profile of the respondents, mass media exposure, information source utilization and internet exposure.

\section{Socio-personal profile of respondents}

Age

The study revealed that data 43 per cent of respondents were from below 35 years age group, which was followed by 35 per cent of respondents from 36-50 years age group and 22 per cent of respondents belonged to 50 years of age in rural area (Table 1).

In urban area, nearly half of the respondents (45\%) were from below 35 years age group, which was followed by 36 per cent of respondents from 36-50 years age group and 19 per cent of respondents were above 50 years of age group. In case of pooled sample, 44 per cent of respondents were from below 35 years of age group, which was followed by respondents $(35.5 \%)$ from $36-50$ years of age group and 20.5 per cent of the respondents belonged to above 50 years of age group.

\section{Education}

Level of education of the respondents was measured in terms of number of years of formal schooling undergone by them. The data 
in Table 1 indicates that 44 per cent of the respondents of rural area were higher secondary, followed by graduate $(41 \%)$. In case of urban area, more than half of the respondents $(54 \%)$ were graduated, which was followed by postgraduate respondents (29\%).

In case of pooled sample, less than half of respondents $(47.5 \%)$ were graduated, which was followed by higher secondary $(30.5 \%)$. Though, 22 per cent of respondents were postgraduate.

\section{Marital status}

The data related to marital status of the respondent presented in Table 1 reveals that in both areas, i.e., rural and urban, majority of the respondents were unmarried $(73 \%, 56 \%$ each) respectively. Further, 27 per cent of the respondents in rural area and 44 per cent in urban area were married. In case of pooled sample, majority of the respondents (64.5\%) were unmarried and 35.5 per cent of respondents were married.

\section{Family type}

The Table 1 clearly shows that, more than half of the respondents (56\%) had nuclear families, while 44 per cent respondents were having joint families in rural area. In urban area, more than $3 / 4^{\text {th }}$ of the respondents $(78 \%)$ were having nuclear families, which was followed by joint families $(22 \%)$. Whereas, in case of pooled sample, 67 per cent of the respondents belonged to nuclear families and 33 per cent of respondents had joint families.

\section{Family size}

The data regarding family size from Table 1 reveals that half of the respondents $(50 \%)$ of rural area had medium sized families, which was followed by small (40\%) and large family size $(10 \%)$. Whereas, in urban area, nearly
$3 / 4^{\text {th }}$ of the respondents $(72 \%)$ had small sized family, which was followed by medium (21\%) and large families (7\%). In case of pooled sample, similar trend was observed.

\section{Caste}

In case of rural area, nearly half of the respondents $(47 \%)$ were from lower caste, which was followed by higher caste (28\%) and medium caste (25\%).

In urban area, majority of the respondents (59\%) belonged to higher caste, which was followed by medium caste (22\%) and lower caste (19\%). Whereas, in pooled sample, nearly half of the respondents $(43.5 \%)$ were from higher caste, which was followed by lower caste (33\%) and medium caste (23.5\%).

\section{Social participation}

The social participation of respondents was almost nil in rural area (94\%), urban area (76\%), as well as, in pooled sample (85\%). Only small percentage $(5 \%, 11 \%$ and $8 \%$ each) respectively of the respondents were social leaders in rural, urban, as well as, in pooled sample. Further, respondents $(1 \%, 13 \%$ and $7 \%$ each) respectively of rural, urban, as well as, in pooled sample were member of formal organization.

Thus, it can be concluded that majority of respondents from below 35 years of age group were graduated and unmarried, who had nuclear type of family having upto 5 members in a family and belonged to general caste and had no membership.

\section{Economic profile of respondents}

Distribution of the respondents according to their economic characteristics has been incorporated in Table 2, which is presented below 


\section{Monthly income}

A perusal of Table 2 clearly depicts that monthly income of most of the respondents of urban area $(60 \%)$ were in the range above Rs. 10,001 , which was followed by the range upto Rs. 5,000 (21\%) and range between Rs. 5,001Rs. 10,000 (19\%). In case of rural area, nearly half of respondents $(48 \%)$ had income upto Rs. 5,000, which was followed by income above Rs. 10,001 (28\%) and between Rs. 5,001-Rs. 10,000 (24\%) per month. In pooled sample, 44 per cent of the respondents were having monthly income above Rs. 10,001, which was followed by income upto Rs. 5,000 and between Rs. 5,001-Rs. 10,000 (34.5\% and $21.5 \%$ each) respectively.

\section{Occupation}

It is clear from Table 2 that in urban area, nearly half of the respondents $(45 \%)$ were doing independent profession, which was followed by students (29\%), agriculture labour and service (10\% each) respectively and 6 per cent of the respondents were doing farming. Whereas, in rural area, 28 per cent of the respondents were doing farming, followed by students (26\%), independent profession $(21 \%)$, service $(15 \%)$ and agriculture labour $(10 \%)$ respectively. In case of pooled sample, 33 per cent of the respondents were engaged in independent profession, which was followed by students $(27.5 \%)$, farming $(17 \%)$, service $(12.5 \%)$ and agriculture labour $(10 \%)$.

\section{House type}

The data in Table 2 depicts that, in urban area, majority of the respondents had pucca house (96\%). Only 4 per cent of the respondent had mixed house. In case of rural area, again majority of the respondents $(60 \%)$ had pucca house, which was followed by mixed house (33\%). Only 7 per cent of the respondent had kaccha house. In case of pooled sample, more than $3 / 4^{\text {th }}$ of the respondents $(78 \%)$ had pucca house, which was followed by mixed house $(18.5 \%)$ and kaccha house $(3.5 \%)$.

\section{Land Holding}

A perusal of Table 2 clearly shows that in urban area, 32 per cent of the respondents were having no land, while 22 per cent of the respondent had marginal and small size of land holding, which was followed by large and medium size land holding $(13 \%$ and $11 \%$ each) respectively. In rural area, nearly half of the respondents (42\%) were having no land, which was followed by marginal, small, medium and large size land holding (28\%, $20 \%, 9 \%$ and $1 \%$ each) respectively. Whereas, in aggregate 37 per cent of the respondents were landless, which was followed by marginal, small, medium and large size of land holding $(25 \%, 21 \%, 10 \%$ and $7 \%$ each) respectively.

Thus, it can be concluded that majority of respondents had their own independent profession with the monthly income above Rs.10, 000, who had pucca house and were landless.

\section{Village infrastructure}

The data pertaining to village infrastructure reported in Table 3 brings to the light that in Ludas and Shahpur, total area was 625 hectares and 1,297 hectares respectively. Total population of both the villages was found to be 3,905 and 5,559 respectively Out of which, 2,255 and 3,141 were males respectively and 650 and 2,418 females respectively with 692 and 1,017 households respectively.

The distance taken from nearest town was 8 $\mathrm{km}$ from Ludas and $13 \mathrm{~km}$ from Shahpur. A railway station was near about 5-10 km away from Ludas and within $5 \mathrm{~km}$ from Shahpur to Hisar. 


\section{Communication profile of the respondents}

The communication pattern of the respondents was analyzed through three parameters viz. mass media exposure, information source utilization and internet exposure.

\section{Mass media exposure}

The data presented in Table 4 and 5 points to the fact that 93 per cent of the respondents in rural area had possession of mass media as Cable TV, which was followed by television (74\%), newspaper (66\%), books (57\%), films (48\%), radio (34\%), magazine $(29 \%)$, leaflets/pamphlets $(21 \%)$, newsletters $(15 \%)$, handouts (16\%) and slides (12\%). Whereas, in urban area, majority of the respondents (97\%) had mass media as newspaper, followed by Cable TV (94\%), television and newsletters (84\% each), books (63\%), magazine (57\%), radio $(49 \%)$, leaflets/pamphlets and films (37\%), handouts $(30 \%)$ and slides (23\%) respectively.

The Table further depicts that, in rural area, 36 per cent of the respondents had medium level mass media exposure, which was followed by low exposure $(35 \%)$ and high exposure (29\%). While, in urban area, more than half of the respondents (57\%) had high mass media exposure, which was followed by medium exposure (28\%) and low exposure (15\%). Thus, in case of pooled weighted mean, nearly half of the respondents (43\%) had high mass media exposure, which was followed by medium exposure (32\%) and low exposure (25\%). Thus, it can be concluded that majority of respondents had possession of Cable TV, followed by television and newspaper and had high mass media exposure (Fig. 1).

\section{Information source utilization}

Regarding utilization of localite sources, it can be observed from Table 6 that in rural area, more than half of the respondents (57\%) had high utilization of localite sources, which was followed by medium (32\%) and low utilization $(11 \%)$. Whereas, in urban area, nearly half of the respondents (45\%) had high utilization of localite sources, which was followed by low (28\%) and medium (27\%).

Thus, in case of pooled sample mean, it was found that half of the respondents $(51 \%)$ had high utilization of localite sources, which was followed by medium (29.5\%) and low $(19.5 \%)$.

Further, regarding utilization of cosmopolite sources, it can be observed in Table 6 that in rural area, majority of respondents $(69 \%)$ had low utilization, which was followed by medium (24\%) and high (7\%). While, in urban area, 63 per cent of the respondents had low utilization of cosmopolite sources, which was followed by medium (28\%) and high (9\%).

Thus, similar trend was followed in case of pooled sample mean. Thus, it can be concluded that majority of respondents had high utilization of localite sources and low utilization of cosmopolite sources (Fig. 2).

\section{Internet exposure of digital methods for using cash less system by respondents}

Majority of respondents in rural area had exposure of PayTm which was given first rank, followed by internet banking (II ${ }^{\text {nd }}$ rank), debit card (III ${ }^{\text {rd }}$ card), credit card ( $\mathrm{IV}^{\text {th }}$ rank), cheque ( $\mathrm{V}^{\text {th }}$ rank), demand draft ( $\mathrm{VI}^{\text {th }}$ rank), BHIM app (VII ${ }^{\text {th }}$ rank), SBI buddy (VIII ${ }^{\text {th }}$ rank), MobiKwik (IX ${ }^{\text {th }}$ rank), PayPal ( $\mathrm{X}^{\text {th }}$ rank), National Electronic Funds Transfer (XI ${ }^{\text {th }}$ rank), mobile wallets, Unified Payments Interface and Gift card (XII ${ }^{\text {th }}$ rank), Immediate Payment Service (XIII ${ }^{\text {th }}$ rank), e-wallet $\left(\right.$ XIV $^{\text {th }}$ rank), Aadhar Enabled Payment System (XV ${ }^{\text {th }}$ rank) and Real Time Gross Settlement System $\left(\mathrm{XVI}^{\text {th }}\right.$ rank) respectively (Table 7). 
Table.1 Socio-personal profile of respondents

\begin{tabular}{|c|c|c|c|c|c|}
\hline \multirow[t]{2}{*}{ Sr. No. } & \multirow[t]{2}{*}{ Variables } & \multirow[t]{2}{*}{ Category } & $\begin{array}{c}\text { Rural } \\
(n=100)\end{array}$ & $\begin{array}{c}\text { Urban } \\
(n=100)\end{array}$ & $\begin{array}{c}\text { Total } \\
(\mathbf{N}=\mathbf{2 0 0})\end{array}$ \\
\hline & & & $(\%)$ & $(\%)$ & $\mathbf{f}(\%)$ \\
\hline \multirow[t]{3}{*}{1.} & \multirow[t]{3}{*}{ Age (Years) } & Below 35 & 43.00 & 45.00 & $88(44.00)$ \\
\hline & & $36-50$ & 35.00 & 36.00 & $71(35.50)$ \\
\hline & & Above 50 & 22.00 & 19.00 & $41(20.50)$ \\
\hline \multirow[t]{2}{*}{2.} & \multirow[t]{2}{*}{ Sex } & Male & 50.00 & 50.00 & $100(50.00)$ \\
\hline & & Female & 50.00 & 50.00 & $100(50.00)$ \\
\hline \multirow[t]{3}{*}{3.} & \multirow[t]{3}{*}{ Education } & Higher Secondary & 44.00 & 17.00 & $61(30.50)$ \\
\hline & & Graduation & 41.00 & 54.00 & $95(47.50)$ \\
\hline & & Post-Graduation & 15.00 & 29.00 & $44(22.00)$ \\
\hline \multirow[t]{2}{*}{4.} & \multirow[t]{2}{*}{ Marital status } & Unmarried & 73.00 & 56.00 & $129(64.50)$ \\
\hline & & Married & 27.00 & 44.00 & $71(35.50)$ \\
\hline \multirow[t]{2}{*}{5.} & \multirow[t]{2}{*}{ Family type } & Nuclear & 56.00 & 78.00 & $134(67.00)$ \\
\hline & & Joint & 44.00 & 22.00 & $66(33.00)$ \\
\hline \multirow[t]{3}{*}{6.} & \multirow[t]{3}{*}{ Family size } & Up to 5 members & 40.00 & 72.00 & $112(56.00)$ \\
\hline & & 6-10 members & 50.00 & 21.00 & $71(35.50)$ \\
\hline & & More than 10 members & 10.00 & 07.00 & $17(08.50)$ \\
\hline \multirow[t]{3}{*}{7.} & \multirow[t]{3}{*}{ Caste } & SC/ST & 47.00 & 19.00 & $66(33.00)$ \\
\hline & & $\mathrm{BC} / \mathrm{OBC}$ & 25.00 & 22.00 & $47(23.50)$ \\
\hline & & General & 28.00 & 59.00 & $87(43.50)$ \\
\hline \multirow[t]{2}{*}{8.} & \multirow[t]{2}{*}{ Locality } & Rural & 100.0 & 00.00 & $100(50.00)$ \\
\hline & & Urban & 00.00 & 100.0 & $100(50.00)$ \\
\hline \multirow[t]{3}{*}{9.} & \multirow[t]{3}{*}{ Social participation } & No Membership & 94.00 & 76.00 & $170(85.00)$ \\
\hline & & Member of formal organization & 01.00 & 13.00 & $14(07.00)$ \\
\hline & & Social leader & 05.00 & 11.00 & $16(08.00)$ \\
\hline
\end{tabular}

Figures in parentheses indicate percentage

Table.2 Economic profile of respondents

\begin{tabular}{|c|c|c|c|c|c|}
\hline \multirow[t]{2}{*}{$\begin{array}{l}\text { Sr. } \\
\text { No. }\end{array}$} & \multirow[t]{2}{*}{ Variables } & \multirow[t]{2}{*}{ Category } & $\begin{array}{c}\text { Rural } \\
(n=100)\end{array}$ & $\begin{array}{c}\text { Urban } \\
(n=100)\end{array}$ & $\begin{array}{c}\text { Total } \\
(\mathrm{N}=\mathbf{2 0 0})\end{array}$ \\
\hline & & & $(\%)$ & $(\%)$ & $\mathbf{f}(\%)$ \\
\hline \multirow[t]{3}{*}{1.} & Monthly income & Up to Rs. 5,000 & 48.00 & 21.00 & $69(39.50)$ \\
\hline & & Rs. 5,001-Rs. 10,000 & 24.00 & 19.00 & $43(21.50)$ \\
\hline & & Above Rs. 10,000 & 28.00 & 60.00 & $88(44.00)$ \\
\hline \multirow[t]{5}{*}{2.} & \multirow[t]{5}{*}{ Occupation } & Agriculture labour & 10.00 & 10.00 & $20(10.00)$ \\
\hline & & Independent profession & 21.00 & 45.00 & $66(33.00)$ \\
\hline & & Farming & 28.00 & 06.00 & $34(17.00)$ \\
\hline & & Service & 15.00 & 10.00 & $25(12.50)$ \\
\hline & & Students & 26.00 & 29.00 & $55(27.50)$ \\
\hline \multirow[t]{3}{*}{3.} & \multirow[t]{3}{*}{ House type } & Kaccha & 07.00 & 00.00 & $07(03.50)$ \\
\hline & & Mixed & 33.00 & 04.00 & $37(18.50)$ \\
\hline & & Pucca & 60.00 & 96.00 & $156(78.00)$ \\
\hline \multirow[t]{5}{*}{4.} & \multirow[t]{5}{*}{ Land holding } & Landless & 42.00 & 32.00 & $74(37.00)$ \\
\hline & & Marginal & 28.00 & 22.00 & $50(25.00)$ \\
\hline & & Small & 20.00 & 22.00 & $42(21.00)$ \\
\hline & & Medium & 09.00 & 11.00 & $20(10.00)$ \\
\hline & & Large & 01.00 & 13.00 & $14(07.00)$ \\
\hline
\end{tabular}


Table.3 Village infrastructure

\begin{tabular}{|c|c|c|c|}
\hline Sr. No. & Village infrastructure & Ludas & Shahpur \\
\hline $\mathbf{1 .}$ & Area & 625 hectares & 1,297 hectares \\
\hline $\mathbf{2 .}$ & Population & 3,905 & 5,559 \\
\hline $\mathbf{3 .}$ & Male & 2,255 & 3,141 \\
\hline $\mathbf{4 .}$ & Female & 650 & 2,418 \\
\hline $\mathbf{5 .}$ & Households & 692 & 1,017 \\
\hline $\mathbf{6 .}$ & Distance from nearest town (Hisar) & $8 \mathrm{~km}$ & $13 \mathrm{~km}$ \\
\hline $\mathbf{7 .}$ & Distance from railway station & $5-10 \mathrm{~km}$ & Within $5 \mathrm{~km}$ \\
\hline
\end{tabular}

Table.4 Possession of mass media by respondents for attaining information regarding cash less system

\begin{tabular}{|c|c|c|c|c|}
\hline Sr. No. & Mass media & $\begin{array}{c}\text { Rural } \\
(\mathbf{\%}) \\
(\mathbf{n = 1 0 0})\end{array}$ & $\begin{array}{c}\text { Urban } \\
(\mathbf{\%}) \\
(\mathbf{n = 1 0 0})\end{array}$ & $\begin{array}{c}\text { Total } \\
\mathbf{f}(\mathbf{\%}) \\
(\mathbf{N}=\mathbf{2 0 0})\end{array}$ \\
\hline $\mathbf{1 .}$ & Radio & 34.00 & 49.00 & $83(41.50)$ \\
\hline $\mathbf{2 .}$ & Television & 74.00 & 84.00 & $158(79.00)$ \\
\hline $\mathbf{3 .}$ & Newspaper & 66.00 & 97.00 & $163(81.50)$ \\
\hline $\mathbf{4 .}$ & Magazine & 29.00 & 57.00 & $86(43.00)$ \\
\hline $\mathbf{5 .}$ & Cable T.V & 93.00 & 94.00 & $187(93.50)$ \\
\hline $\mathbf{6 .}$ & Books & 57.00 & 63.00 & $120(60.00)$ \\
\hline $\mathbf{7 .}$ & Newsletters & 15.00 & 84.00 & $99(49.50)$ \\
\hline $\mathbf{8 .}$ & Leaflets/ Pamphlets & 21.00 & 37.00 & $58(29.00)$ \\
\hline $\mathbf{9 .}$ & Handouts & 16.00 & 30.00 & $46(23.00)$ \\
\hline $\mathbf{1 0 .}$ & Slides & 12.00 & 23.00 & $35(17.50)$ \\
\hline $\mathbf{1 1 .}$ & Films & 48.00 & 37.00 & $85(42.50)$ \\
\hline
\end{tabular}

Figures in parentheses indicate percentage

Table.5 Mass media exposure of respondents for attaining information regarding cash less system

\begin{tabular}{|c|c|c|c|c|}
\hline $\begin{array}{c}\text { Sr. } \\
\text { No. }\end{array}$ & Mass media & $\begin{array}{c}\text { Rural } \\
(\mathbf{\%}) \\
(\mathbf{n = 1 0 0})\end{array}$ & $\begin{array}{c}\text { Urban } \\
(\mathbf{\%}) \\
(\mathbf{n = 1 0 0})\end{array}$ & $\begin{array}{c}\text { Total } \\
\mathbf{f}(\mathbf{\%}) \\
(\mathbf{N}=\mathbf{2 0 0})\end{array}$ \\
\hline i. & Low & 35.00 & 15.00 & $50(25.00)$ \\
\hline ii. & Medium & 36.00 & 28.00 & $64(32.00)$ \\
\hline iii. & High & 29.00 & 57.00 & $86(43.00)$ \\
\hline
\end{tabular}

Figures in parentheses indicate percentage

Table.6 Information source utilization for cash less system by respondents

\begin{tabular}{|c|c|c|c|c|}
\hline Sr. No. & Information source utilization & $\begin{array}{c}\text { Rural } \\
(\%) \\
(n=100)\end{array}$ & $\begin{array}{c}\text { Urban } \\
(\%) \\
(n=100)\end{array}$ & $\begin{array}{c}\text { Total } \\
\mathbf{f}(\%) \\
(\mathbf{N}=\mathbf{2 0 0})\end{array}$ \\
\hline (a) & \multicolumn{4}{|c|}{ Localite Sources } \\
\hline & Low & 11 & 28 & $39(19.50)$ \\
\hline & Medium & 32 & 27 & $59(29.50)$ \\
\hline & High & 57 & 45 & $102(51.00)$ \\
\hline \multirow[t]{4}{*}{ (b) } & \multicolumn{4}{|c|}{ Cosmopolite sources } \\
\hline & Low & 69 & 63 & $132(66.00)$ \\
\hline & Medium & 24 & 28 & $52(26.00)$ \\
\hline & High & 07 & 09 & $16(08.00)$ \\
\hline
\end{tabular}

Figures in parentheses indicate percentage 
Table.7 Internet exposure of digital methods for using cash less system by respondents

\begin{tabular}{|c|c|c|c|c|c|c|c|c|c|c|c|c|c|}
\hline \multirow[t]{2}{*}{$\begin{array}{c}\text { Sr. } \\
\text { No. }\end{array}$} & \multirow[t]{2}{*}{ Attributes } & \multicolumn{5}{|c|}{$\begin{array}{c}\text { Rural } \\
(n=100)\end{array}$} & \multicolumn{5}{|c|}{$\begin{array}{c}\text { Urban } \\
(n=100)\end{array}$} & \multicolumn{2}{|c|}{$\begin{array}{c}\text { Total } \\
(\mathbf{N}=\mathbf{2 0 0})\end{array}$} \\
\hline & & $\begin{array}{c}\text { High } \\
(3)\end{array}$ & $\begin{array}{l}\text { Moderate } \\
\text { (2) }\end{array}$ & $\begin{array}{l}\text { Low } \\
\text { (1) }\end{array}$ & $\begin{array}{c}\text { Weighted } \\
\text { Mean Score }\end{array}$ & Rank & $\begin{array}{c}\text { High } \\
\text { (3) }\end{array}$ & $\begin{array}{l}\text { Moderate } \\
\text { (2) }\end{array}$ & $\begin{array}{l}\text { Low } \\
\text { (1) }\end{array}$ & $\begin{array}{c}\text { Weighted } \\
\text { Mean Score }\end{array}$ & Rank & $\begin{array}{c}\text { Weighted } \\
\text { Mean Score }\end{array}$ & Rank \\
\hline 1. & Pay TM & 32 & 33 & 35 & 1.97 & I & 43 & 30 & 27 & 2.16 & $\mathrm{I}$ & 2.065 & I \\
\hline 2. & PayPal & 04 & 12 & 84 & 1.20 & $\mathrm{X}$ & 03 & 16 & 81 & 1.22 & XII & 1.210 & XI \\
\hline 3. & MobiKwik & 05 & 17 & 78 & 1.27 & IX & 10 & 15 & 75 & 1.35 & $\mathrm{X}$ & 1.310 & IX \\
\hline 4. & BHIM & 09 & 18 & 73 & 1.36 & VII & 24 & 24 & 52 & 1.72 & V & 1.540 & VI \\
\hline 5. & Internet Banking & 30 & 26 & 44 & 1.86 & II & 44 & 34 & 22 & 2.22 & III & 2.040 & III \\
\hline 6. & Credit Card & 25 & 30 & 45 & 1.80 & IV & 44 & 16 & 40 & 2.04 & IV & 1.920 & IV \\
\hline 7. & Debit Card & 24 & 35 & 41 & 1.83 & III & 60 & 20 & 20 & 2.40 & II & 2.115 & II \\
\hline 8. & Cheque & 16 & 39 & 45 & 1.71 & V & 13 & 41 & 46 & 1.67 & VI & 1.690 & V \\
\hline 9. & Demand Draft & 10 & 25 & 65 & 1.45 & VI & 08 & 19 & 73 & 1.35 & $\mathrm{X}$ & 1.400 & VIII \\
\hline 10. & $\begin{array}{c}\text { National Electronic } \\
\text { Funds Transfer } \\
\text { (NEFT) }\end{array}$ & 00 & 10 & 90 & 1.10 & $\mathrm{XI}$ & 04 & 17 & 79 & 1.25 & XI & 1.175 & XV \\
\hline 11. & E-Wallet & 00 & 04 & 96 & 1.04 & XIV & 08 & 20 & 72 & 1.36 & IX & 1.200 & XIV \\
\hline 12. & $\begin{array}{l}\text { Real Time Gross } \\
\text { Settlement (RTGS) }\end{array}$ & 00 & 02 & 98 & 1.02 & XVI & 03 & 12 & 85 & 1.18 & XIII & 1.100 & XVI \\
\hline 13. & Mobile Wallet & 00 & 08 & 92 & 1.08 & XII & 18 & 17 & 65 & 1.53 & VII & 1.305 & $\mathrm{X}$ \\
\hline 14. & $\begin{array}{l}\text { Unified Payments } \\
\text { Interface (UPI) }\end{array}$ & 02 & 04 & 94 & 1.08 & XII & 17 & 19 & 64 & 1.53 & VII & 1.305 & $X$ \\
\hline 15. & Gift Card & 03 & 02 & 95 & 1.08 & XII & 04 & 09 & 87 & 1.17 & XIV & 1.125 & XIII \\
\hline 16. & $\begin{array}{c}\text { Aadhar Enabled } \\
\text { Payment System } \\
\text { (AEPS) }\end{array}$ & 01 & 01 & 98 & 1.03 & $\mathrm{XV}$ & 09 & 23 & 68 & 1.41 & VIII & 1.220 & XII \\
\hline 17. & $\begin{array}{c}\text { Immediate Payment } \\
\text { Service (IMPS) }\end{array}$ & 00 & 05 & 95 & 1.05 & XIII & 04 & 10 & 86 & 1.18 & XIII & 1.115 & XVI \\
\hline 18. & SBI Buddy & 06 & 17 & 77 & 1.29 & VIII & 24 & 19 & 57 & 1.67 & VI & 1.480 & VII \\
\hline
\end{tabular}

Low: $1.00-1.66 \quad$ Medium: 1.67-2.32 High: 2.33-3.00 
Fig.1 Mass media exposure of respondents for attaining information regarding cash less system

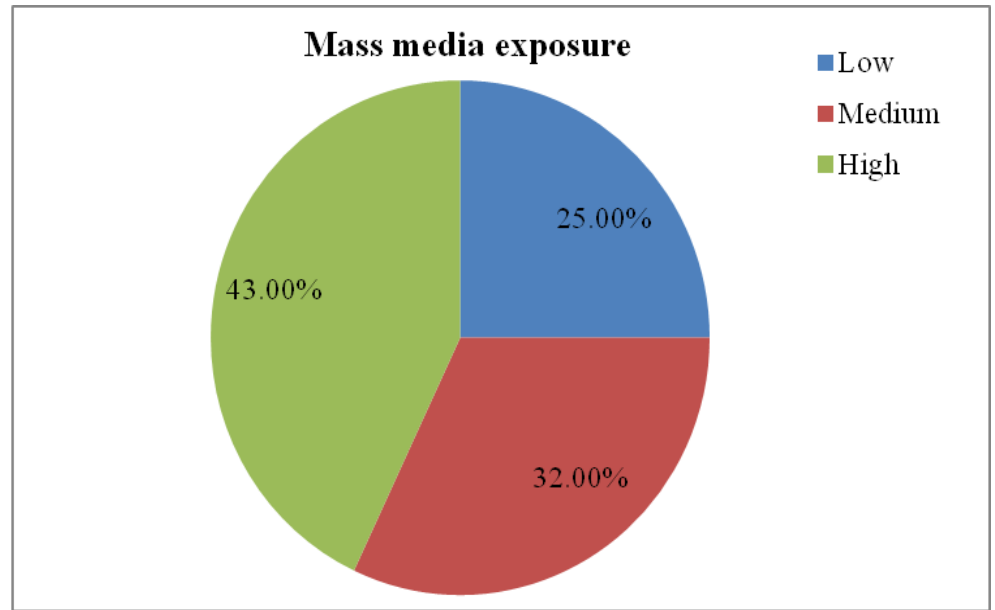

Fig.2 Information source utilization for cash less system by respondents
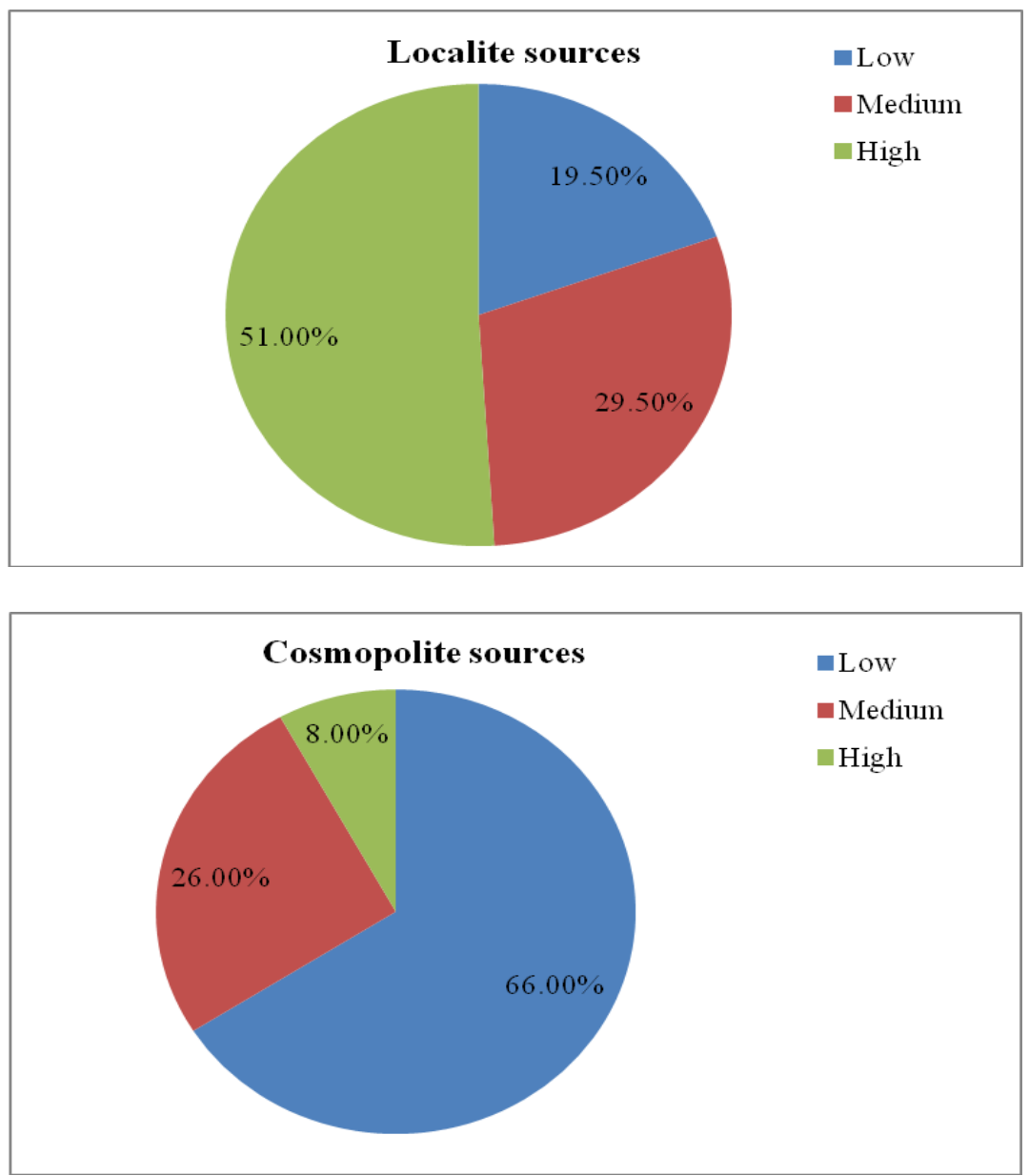
Whereas, in urban area, majority of respondents had exposure of PayTm which was given first rank, followed by debit card (II ${ }^{\text {nd }}$ rank), internet banking (III ${ }^{\text {rd }}$ card), credit card (IV ${ }^{\text {th }}$ rank), BHIM app ( $\mathrm{V}^{\text {th }}$ rank), cheque (VI ${ }^{\text {th }}$ rank), $)$, mobile wallets and Unified Payments Interface (VII ${ }^{\text {th }}$ rank), Aadhar Enabled Payment System (VIII ${ }^{\text {th }}$ rank), e-wallet (IX ${ }^{\text {th }}$ rank), MobiKwik and demand draft $\left(\mathrm{X}^{\text {th }}\right.$ rank each) respectively, National Electronic Funds Transfer (XI ${ }^{\text {th }}$ rank), PayPal (XII ${ }^{\text {th }}$ rank), Real Time Gross Settlement System and Immediate Payment Service (XIII ${ }^{\text {th }}$ rank each) and Gift card (XIV ${ }^{\text {th }}$ rank) respectively.

Thus, in case of pooled weighted mean, it was found that majority of respondents had exposure of PayTm which was given first rank, followed by debit card (II ${ }^{\text {nd }}$ rank), internet banking (III ${ }^{\text {rd }}$ rank), credit card (IV ${ }^{\text {th }}$ rank), cheque ( $\mathrm{V}^{\text {th }}$ rank), BHIM app (VI ${ }^{\text {th }}$ rank), SBI buddy (VII ${ }^{\text {th }}$ rank), demand draft (VIII $^{\text {th }}$ rank), MobiKwik (IX ${ }^{\text {th }}$ rank), mobile wallet and Unified Payments Interface ( $\mathrm{X}^{\text {th }}$ rank), PayPal ( $\mathrm{XI}^{\text {th }}$ rank), Aadhar Enabled Payment System (XII ${ }^{\text {th }}$ rank), Gift card (XIII $^{\text {th }}$ rank), e-wallet $\left(\mathrm{XIV}^{\text {th }}\right.$ rank), National Electronic Funds Transfer ( $\mathrm{XV}^{\text {th }}$ rank), Real Time Gross Settlement System and Immediate Payment Payment Service (XVI ${ }^{\text {th }}$ rank each) respectively.

Thus, it can be concluded that majority of respondents had exposure of PayTm for using cashless system, followed by credit card and internet banking.

Therefore, it can be concluded that the socioeconomic personal profile of the respondents revealed that 44 per cent of the respondents were below 35 years of age group, educated up to graduated and unmarried, who had nuclear type of family having up to 5 members in a family and belonged to general caste and had no membership. Most of the respondents had their own independent profession with monthly income above Rs.10, 000, who had pucca house and were landless. Majority of the respondents had possession of Cable TV, followed by television and newspaper and had high mass media exposure. As far as information source utilization, majority of the respondents had high utilization of localite sources and low utilization of cosmopolite sources. As regards of internet exposure of digital methods, majority of the respondents had exposure of PayTm for using cashless system, followed by credit card and internet banking.

\section{References}

Ejiro, O. 2012. What Nigerians think of the cashless economy policy? Nigerian Journal of Economy, 4(6): 97-102.

Garg, P. and Panchal, M. 2017. Study on Introduction of Cashless Economy in India 2016: Benefits \& Challenge's. Journal of Business and Management, 19(4): 116-120.

Shoopard, W. 2016. A Cashless Future Is The Real Goal Of India's Demonetization Move.

https://www.forbes.com/sites/wadeshepa rd/2016/12/14/inside-indias-cashlessrevolution/\#4d21321f4d12.

Swetha and Venkatesh, B.R. 2019. A Study On Impact of Cashless Transactions on Sale of Branded Household Durables With Respect To Chickballapura and Kolar Districts. International Journal of Management, Technology and Engineering: 2249-7455.

\section{How to cite this article:}

Manisha Ohlan, Ella Rani and Autade, C.D. 2019. Socio-Economic and Communication Profile for using Cashless System by Respondents. Int.J.Curr.Microbiol.App.Sci. 8(11): 830-839. doi: https://doi.org/10.20546/ijcmas.2019.811.098 